\title{
ASSESSMENT OF AEC SYSTEM RESPONSE IN GE 16 SLICES SCANNER
}

\author{
Vesna Gershan \\ Institute of Physics, Faculty of Natural Sciences and Mathematics, \\ Ss. Cyril and Methodius University, Skopje, Republic of Macedonia \\ e-mail: vgersan@gmail.com
}

\begin{abstract}
Computed Tomography scanners equipped with system for Automatic Exposure Control (AEC) have been recently installed into clinical practice in Macedonia. Assessment of their AEC settings and performances is important task from patient doses and images quality point of view. This study was done by analyzing of CT examinations in patients in the City Hospital "8 September" in Skopje. The examinations were carried out by GE Bright Speed 16 slices scanner equipped with AEC system. In all patients were applied the same protocol with constant acquisition parameters was applied, and images were reconstructed by standard mode. Patient dimensions and image noise were measured from the scouts and axial images. From DICOM header the information related to dose, TCM and slice position were extracted. It was found that scanner automatic exposure system adjusts exposure mainly according to maximal patient lateral dimension (LR) and applying the same Noise Index (NI) value in patients with different size does not provides necessarily the same image noise level. In patients which LR dimension was less than $30 \mathrm{~cm}$ it was found that $\mathrm{AEC}$ adjusts tube current at the minimum of $\mathrm{mA}$ interval with no modulation throughout different body parts.
\end{abstract}

Key words: AEC response in CT; tube current modulation; image noise; noise index

\section{INTRODUCTION}

In the last ten to fifteen years, there is a sharp increase in the number of installed CT scanners in the Republic of Macedonia. While in 2000 there were less than ten CT scanners, in 2013 there were more than 35 CT scanners installed on the territory of the Republic of Macedonia. According to a European survey conducted in 2011 on the population doses from medical procedures, the number of available CT scanners in the Republic of Macedonia per million populations is higher than that of the United Kingdom or of Slovenia, for example [1]. This leaded to significant increase of the number and the type of performed CT examinations, as well as of the number of patients with multiple studies and follow-up examinations. Therefore it is highly important for patients to perform CT scanning with the most optimal dose in terms of required clinical image quality.

New clinical applications for CT and development of scanners with more detector arrays and more possibilities, led to considerable different ap- proaches in clinical practice. With the introduction of faster multidetector CT scanners, various techniques have been developed to reduce the radiation dose to the patients. One of them is the system for Automatic Exposure Control (AEC) which is analogous to automatic exposure control techniques used in radiography. A key parameter affecting dose to the patient is the selected tube current-time product (mAs).

When using the AEC system, some way of prescribing the tube current (mA), and thereby the desired level of image quality must be adopted. AEC systems operate on the basis of several methods: standard deviation, noise index, reference $\mathrm{mAs}$ and reference image quality. On some systems the tube current (mA), which would be used without AEC on a standard-sized patient, is input, and this value is used as the base-line for calculating the $\mathrm{mA}$ needed to obtain the same noise level for different patient sizes. Other systems require an 'image quality' index to be input. This index is usually related to the 
noise value (standard deviation of the CT numbers in a water phantom), and the $\mathrm{mA}$ is adjusted to maintain this prescribed noise level for all patient sizes. A third approach is to select a so call 'reference image' with the required level of image noise for a particular examination. This image is then used to adjust the $\mathrm{mA}$ such that the same level of image noise is achieved for each patient. In addition to the various methods for prescribing the tube current there is usually an option to set the upper and lower limits of the mA used by the AEC system [2,3,4].

Automatic adjustment of tube current is not only a useful dose reduction tool but can also lead to benefits in image quality. It should result in more consistent image quality from patient to patient, from slice to slice, and within a slice. Modulation of $\mathrm{mA}$ throughout a rotation can also reduce streaking artefacts caused by low photon flux in the lateral projections of anatomical areas such as the shoulders and pelvis. An added advantage of automatic $\mathrm{mA}$ control is that since it is designed to use lower overall mAs values, the heat capacity of the tube is preserved, allowing for longer scan lengths if there is a need, and for a longer tube life.

However, it is also important to note that although AEC systems are often marketed as dosereduction tools, it is perfectly possible to operate them at a higher radiation dose than it would be obtained without their use. Careful prescription of the mAs or image quality is needed to ensure that doses are optimised and within reference dose values. A clear understanding of how to use different AEC systems on different multidetector CT scanners will allow users to modulate radiation dose, reduce photon starvation artefacts, and maintain the same image quality throughout the different body parts.

Automatic mA adjustment requires prior knowledge of the attenuation characteristics of a patient. The attenuation of the X-ray beam increases with the thickness of material in its path and for approximately every $4 \mathrm{~cm}$ of soft tissue, the X-ray beam intensity halves. In order to achieve the same transmitted X-ray intensity, and thereby the same level of image noise, changing from a $16 \mathrm{~cm}$ to $20 \mathrm{~cm}$ phantom requires a doubling of the $\mathrm{mA}$ [2].

The attenuation information to adapt the $\mathrm{mA}$ for patient size is obtained from the planning scan projection radiograph (SPR), referred to by different manufacturers as ScoutView, Scanogram or Topogram [5]. The SPR information is also used to adjust the $\mathrm{mA}$ for each rotation.

The purpose of this work was to assess the AEC response and tube current interval adjustments in a particular scanner.

\section{MATERIALS AND METHODS}

The study was done by analyzing $47 \mathrm{CT}$ examinations (11 of abdomen and 36 of abdomen \& pelvis area) in randomly selected adult patients at the Radiology Department in the City Hospital "8 September" in Skopje. The examinations were performed on GE Bright Speed 16 slices scanner equipped with AEC system that has ability for tube current modulation (TCM) across $z$-axis, so called Auto mA feature [6]. Adjustment of the tube current in this type of modulation, can be considered on two levels: at the first level the $\mathrm{mA}$ is adjusted according to overall patient size (Figures $1 \mathrm{a}$ and $1 \mathrm{~b}$ ) and at the second level $\mathrm{mA}$ is adjusted according to attenuation variation within the patient whereas $\mathrm{mA}$ varied on a rotation by rotation (Figure 1c).

Image noise is an important parameter that determines overall image quality. The standard deviation $\sigma$ of $\mathrm{HU}$ is direct indicator about the noise level and it can be computed using the root mean square method according to relation (1):

$$
\sigma=\sqrt{\frac{\sum_{i=1}^{N}(H U-\overline{H U})^{2}}{N-1}}
$$

The noise is reverse proportionally to the square root of dose, i.e. of CT dose index $\left(\mathrm{CTDI}_{\mathrm{vol}}\right)$ parameter (relation 2). For example double the dose and the noise will decrease by $40 \%$, quadruple the dose and the noise will decrease by a factor 2 .

$$
\sigma \sim \sqrt{\frac{1}{C T D I_{v o l}}} \sim \sqrt{\frac{1}{m A}}
$$

Increasing of dose i.e. tube current results in decreasing of noise and vice-versa. It should be mention that the final level of image noise depends not only on applied technique factors, slice thickness, patient attenuation and body shape, but also on image reconstruction filter and reconstruction methods.

In order to provide the same image noise level for the whole scanned body part, TCM will decrease tube current for projections through smaller body parts and will increase it for projections through bigger body parts. On that way tube current modulation technique in CT should ensures dose reduction and provides the same image quality (noise) for patients with different size and for different body regions in one patient.

The AEC tool in GE BrightSpeed scanner uses the scan projection radiography (or scouts General Electric trade mark name for Scan Projection Radiography) made from Lateral (LR) and 
from Anterior-Posterior (AP) projections to calculate the relative patient dimensions in each rotation and $\mathrm{mA}$ is then varied sinusoidally to match this ratio the best [7]. In this type of AEC tool there is a feature so called Noise Index (NI) which allows users to select the amount of noise that will be present in the reconstructed images. So, AEC response depends not only on attenuation data from LR and AP scouts in some particular patient, but also on NI parameter value $[8,9]$.
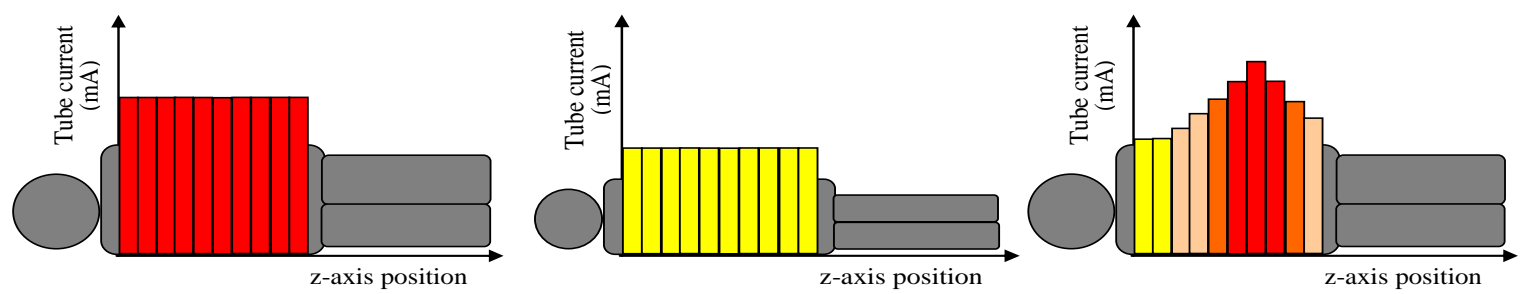

Figure 1. TCM according to patient size and according to different body part

The noise index value is approximately equal to standard deviation in the central region of the image when a uniform phantom (with the patient's attenuation characteristics) is scanned and reconstructed using the standard reconstruction algorithm.

Since CTDI value is proportional on $\mathrm{mA}$ value, this parameter will vary with each patient regardless of applying the same scan protocol.
In all patients a protocol for abdominal scanning with constant acquisition parameters was applied (Table 1). A function which varies $\mathrm{mA}$ in $z$ axis (Auto $\mathrm{mA}$ ) was activated and $\mathrm{mA}$ interval was preset by local GE representatives from 118 minimum to 300 maximum $\mathrm{mA}$ ranges. Noise Index was set on 14.4 and the same value was applied in all acquisition series.

Table 1. Protocol acquisition parameters

\begin{tabular}{cccccc}
\hline $\begin{array}{c}\text { Tube voltage } \\
(\mathrm{kV})\end{array}$ & $\begin{array}{c}\text { Rotation time } \\
(\mathrm{s})\end{array}$ & $\begin{array}{c}\text { Slice thickness } \\
(\mathrm{mm})\end{array}$ & $\begin{array}{c}\text { SFOV } \\
(\mathrm{cm})\end{array}$ & Pitch & Scan mode \\
\hline 120 & 0.8 & 5.0 & 50 & $1.375: 1$ & helical \\
\hline
\end{tabular}

The standard clinical protocol for abdominal and abdominal examinations is consists of four consequent scan series: 1) pre-contrast, 2) dual phase, 3) $1.25 \mathrm{~mm}$ and 4) late phase, with official protocol name "6.7. Dual Phase 5 mm Smart Prep." Images in all series were reconstructed by standard reconstruction mode.

Maximal anterior-posterior (AP) and lateral (LR) dimensions of patients were measured form the scout images as illustrated on Figures $2 \mathrm{a}$ and $2 b$. The effective diameter of the patient at that location was computed by using an equation Eff.diameter $=\sqrt{A P \cdot L R}[10]$.

Image noise was measured at cross section images in pre contrast series at spleen region and $\mathrm{mA}$ value was recorded for that section (Figure 2c).

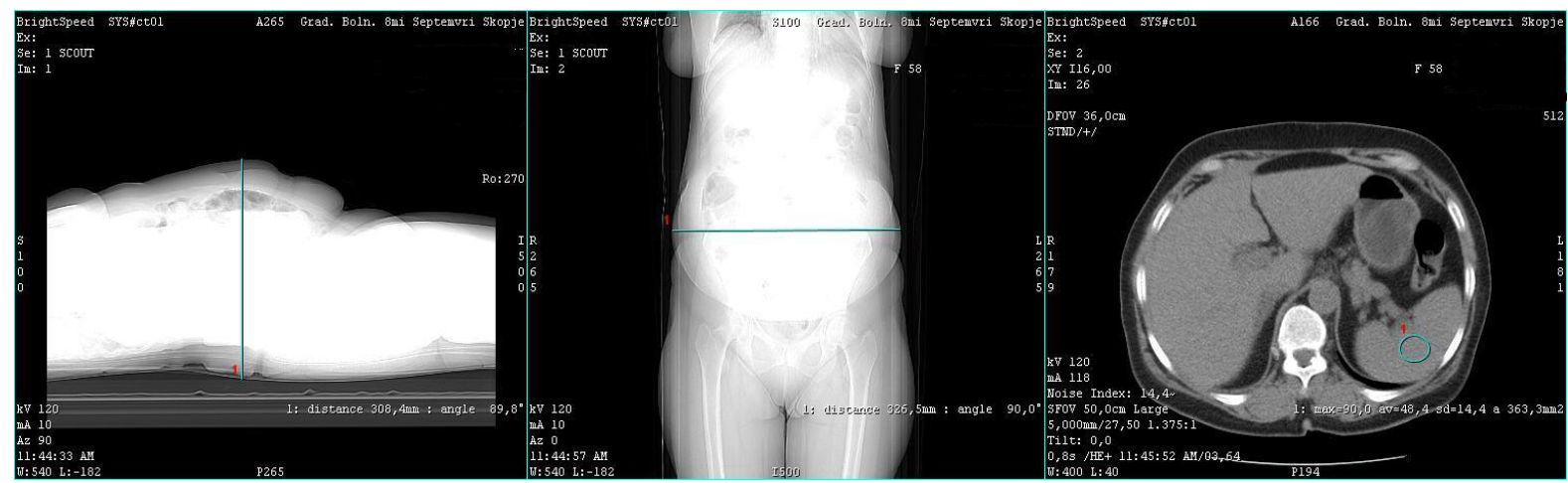

Figure 2a. Anterior-posterior dimension Figure 2b. Lateral dimension

Figure 2c. Noise measurement 
By using a DICOM Extractor tool [11], was extracted data about slice location, corresponding $\mathrm{mA}$ and CTDI values for all series. Since all series were acquired by applying the same exposure factors and $\mathrm{mA}$ adjustments were done from the same scout projections, the assessment of AEC response was done by using data for pre contrast series only.

\section{RESULTS AND DISCUSSION}

In terms to assess which patient dimension has the strongest influence on the $\mathrm{mA}$ modulation, correlations were checked between $\mathrm{CTDI}_{\mathrm{vol}}$ values and AP, LR and effective diameter. It was found that scanner automatic exposure system adjusts exposure mainly according to maximal patient lateral dimension (Figure 3) with coefficient of correlation of 0.79 between CTDI value and LR dimension. Additionally, patient effective diameter AP has stronger influence on TCM than AP patient dimension (Figures 4 and 5) with coefficients of correlation of 0.76 and 0.53 appropriately.

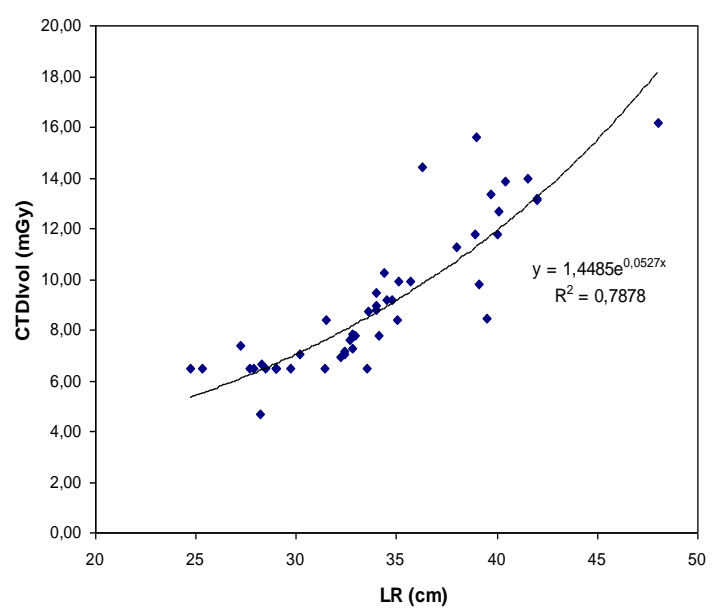

Figure 3. CTDI - Lateral patient dimension correlation

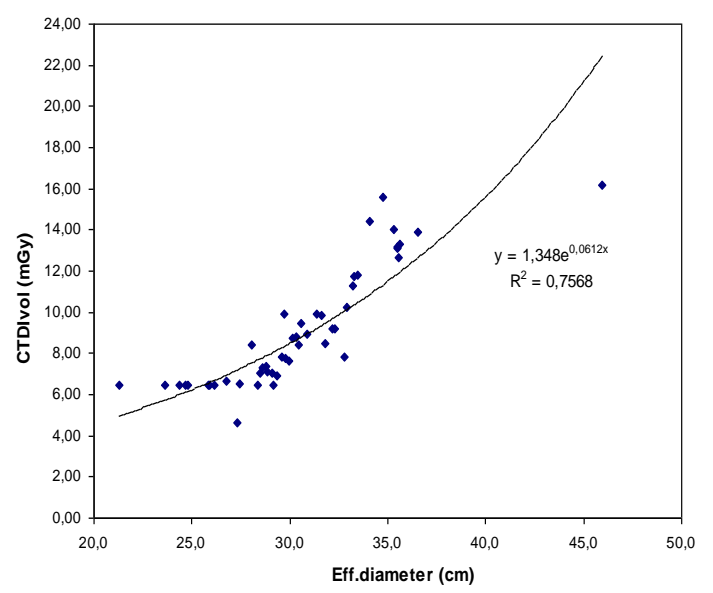

Figure 4. CTDI - Patient effective diameter correlation

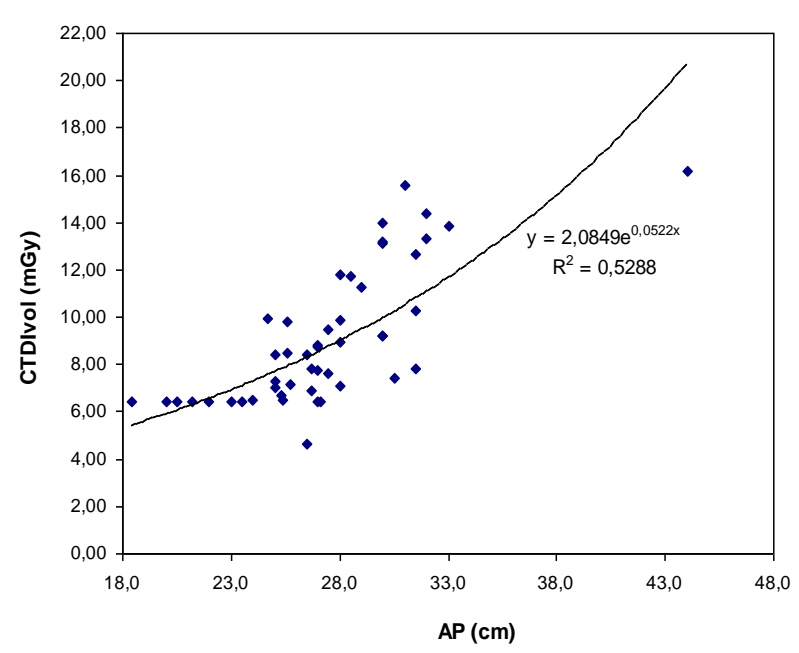

Figure 5. CTDI - Anterior-posterior patient dimension correlation

The most characteristic cases in our study are illustrated on the next figures (Figures 6, 7, 8 and 9 ). The case ilustrated on Figure 6 represents the smallest size patient in our group. It can be noticed that $\mathrm{mA}$ keep on the minimum $\mathrm{mA}$ preset value of 118 and it is constant across different body regions. No changes in $\mathrm{mA}$ values indicate that the minimum of $\mathrm{mA}$ interval, actually is too high for such small patient. As a consequence, patients like this size, will be exposed unnecessarily to higher doses.

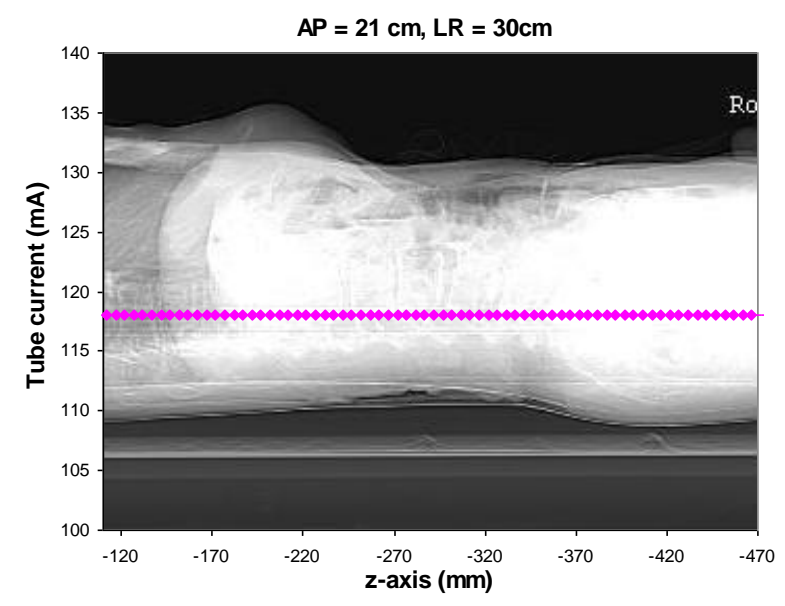

Figure 6. TCM in the smallest patient size

Figure 7 illustrates a case in which the tube current values were $297 \mathrm{~mA}$ for the whole scan range, which was actually the upper limit of the $\mathrm{mA}$ interval. This indicates that in a big size patient the upper limit of $300 \mathrm{~mA}$ could be insufficient to achieve the same image quality. 


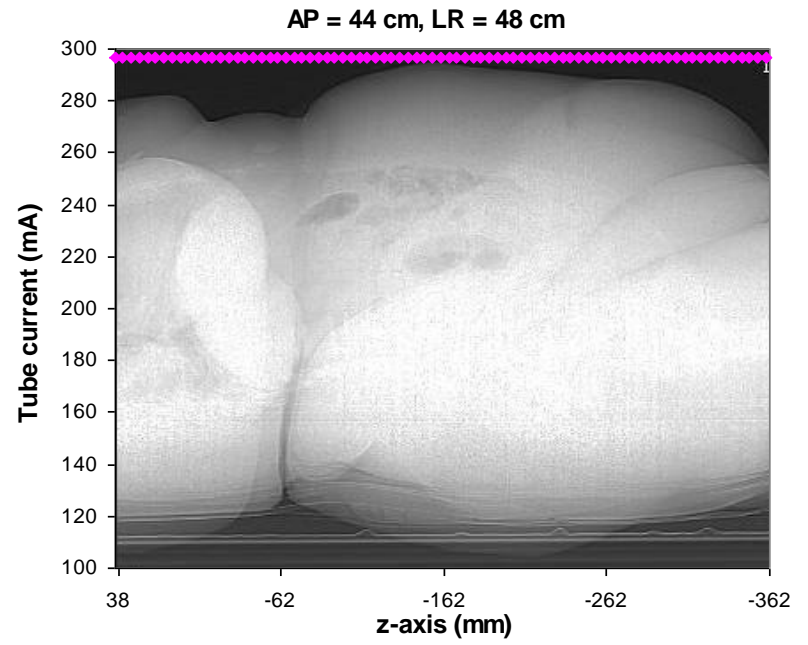

Figure 7. TCM in the largest patient size

Figures 8 and 9 present cases which illustrate $\mathrm{mA}$ modulation across $z$-axis. In the second case, the increase of $\mathrm{mA}$ values in pelvic area is explained due to high attenuation of two artificial hips.

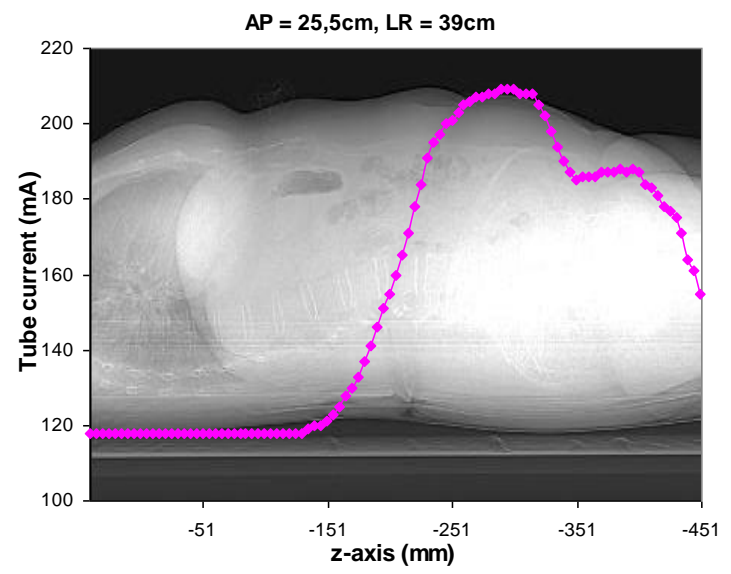

Figure 8. Typical TCM across $z$-axis

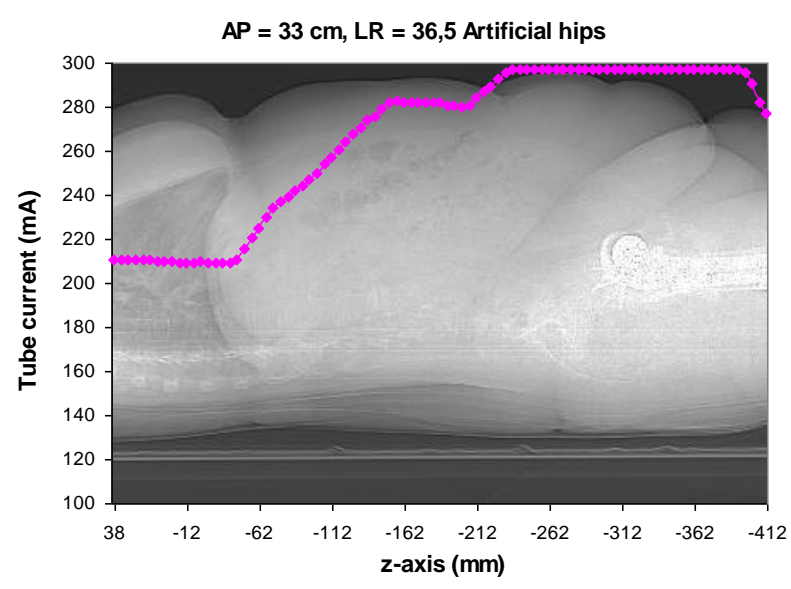

Figure 9. TCM in case of high attenuation objects inside patient body
It was found that measured image noise values in average was close to the predefined target level of NI $=14.4$. But, it was noted a tendency of slight increase of noise level with increasing of lateral patient dimension (Figure 10). The last finding suggests that for different patient sizes AEC tool does not provide the same image noise level. Further analysis is needed for assessment of this noise deviation related to the patient size.

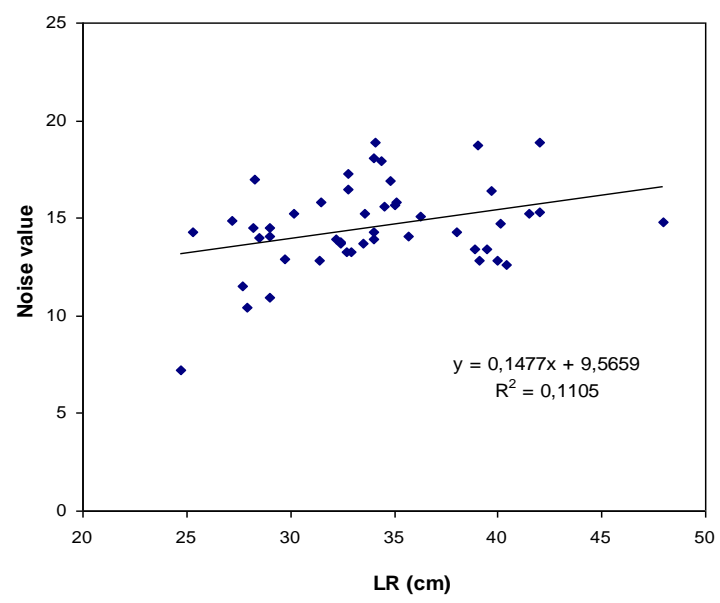

Figure 10. Image noise - lateral patient dimension correlation

For the smaller patients $(\mathrm{LR}<30 \mathrm{~cm})$, the noise was lower than the predefined target level, which could indicate that a slightly higher exposure was delivered to these patients. Possible explanation for this finding may be that for small patients lower current limit $(118 \mathrm{~mA})$ was preset higher than it is optimal at given NI value.

On the Figure 11 there is presented noise $\mathrm{mA}$ correlation for spleen section. As it can be seen, the same $\mathrm{mA}$ does not provide the same noise level.

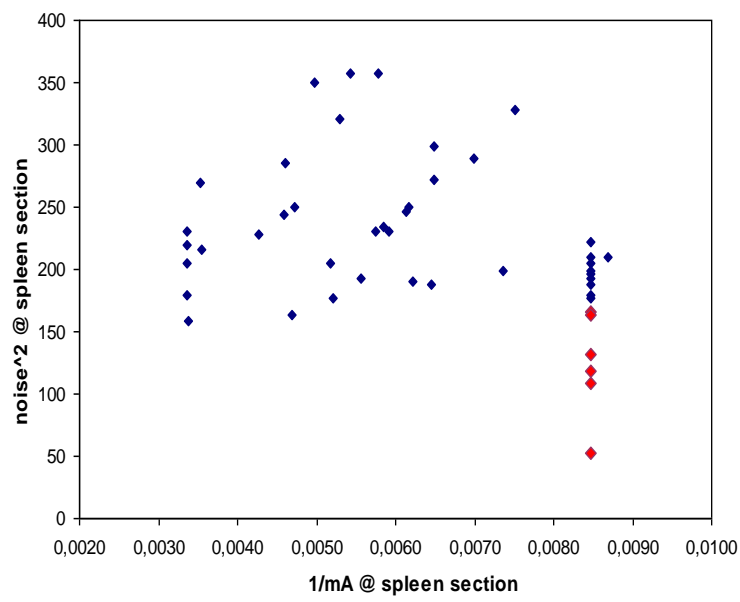

Figure 11. Image noise corresponding tube current value 
In 15 patients (32\%) the AEC adjusted current value of $118 \mathrm{~mA}$ in spleen section. In six of them (which LR was in range of 24-29 cm), noise value was 10.9 in average what is considerably lower than the average noise value of 15.2 in another 42 patients.

\section{CONCLUSION}

In this particular scanner, it was found that automatic exposure system adjusts exposure mainly according to maximal patient lateral dimension.

Findings in this study suggested that applying the same NI value does not necessarily provide the same image noise level in patients with different size. Measured noise level in smaller patients in average was lower than in bigger ones, particularly in patients which LR dimension was less than $30 \mathrm{~cm}$. Additionally, for such patients it was found that AEC adjusted tube current at the minimum of $\mathrm{mA}$ interval with no modulation across different body part. That indicates that the minimal $\mathrm{mA}$ limit was set higher than it should be for that particular NI value and these patients were exposed more than it was necessary to achieve requested image quality.

Tube current modulation is an invaluable dose optimisation tool but relies on the operator selecting of either the $\mathrm{mA}$ interval or the required image noise level i.e. noise index (NI).

Since in CT there is not an image quality penalty for over-exposure, it is very difficult to identify if some patient received higher dose, unless patient dose recording procedure was put in place. Until then, two clinical challenges remain, the first one is to optimize mA interval and NI for different patient size, and the second one is to identify an appropriate image quality made at a minimum dose level for each target organ examination and for every scan series.

Acknowledgment: The author expresses her profound gratitude to Ms. Andonovska, technologist at the
Radiology Department in the City Hospital "8 September" in Skopje, for provided access to the CT exams.

\section{REFERENCES}

[1] Dose DataMed II Project, www.ddmed.eu

[2] M. Lewis, Radiation dose issues in multi-slice CT scanning, 2005, ImPACT technology update, no. 3.

[3] A. Britten et al., The addition of computer simulated noise to investigate radiation dose and image quality in images with spatial correlation of statistical noise: an example application to X-ray CT of the brain, Br J Radiol, 2004; 77:323-8.

[4] M. Kalra et al., CT radiation exposure: Rationale for concern and strategies for dose reduction, $A p$ plied Radiology, 2003; online supplement; Proceedings from the SCBT/MR.

[5] C. H. Lee et al., Radiation Dose Modulation Techniques in the Multidetector CT era: From Basics to Practice, RadioGraphiscs, 2008; 28:1451-145.

[6] N. Keat et al., GE LightSpeed ${ }^{16}$ CT Sanner Technical Evaluation, MHRA Evaluation Report, 2004; MHRA04015.

[7] Scan Faster. Scan Longer. Scan with less dose, T.Toth, Principal Engineer, Global CT Systems, GE Healthcare publication.

[8] Bruesewith et al., Smart mA - Automatic Exposure Control (AEC): Physics principles and practical hints, RSNA 2008.

[9] S. Raman et al., CT Dose reduction application: Available tools on the latest generation of CT scanners, Am Coll Radiol, 2013; 10:37-41.

[10] J. Boone et al., Size-Specific Dose Estimates (SSDE) in Pediatric and Adult Body CT Examinations, Report of AAPM Task Group 204, American Association of Physicists in Medicine, 2011, ISBN 978-1-936366-08-8.

[11] A. Tsalafoutas and S. Metallidis, A method for calculating the dose length product from CT DICOM images, The British Journal of Radiology, 84 (2011), 236-243. 


\title{
ИСПИТУВАЊЕ НА ОДГОВОРОТ НА СИСТЕМОТ ЗА АВТОМАТСКА КОНТРОЛА НА ЕКСПОЗИЦИЈАТА КАЈ GЕ СКЕНЕР СО 16 ПРЕСЕЦИ
}

\author{
Весна Гершан \\ Институт за физика, Природно-математички факултет, \\ Универзитет „Св. Кирил и Методиј“, Скопје, Република Македонија
}

\begin{abstract}
Во клиничката пракса во Македонија неодамна беа инсталирани КТ-скенери опремени со систем за автоматска контрола на експозицијата (АКЕ). Процената на нагоденоста и на перформансите на овие АКЕ системи е важна задача, како од аспект на дозите кај пациентите, така и од аспект на квалитетот на сликите. Ова истражување беше направено анализирајќи ги КТ-снимањата на пациентите во болницата „8-ми септември““ во Скопје. Снимањата беа изведени на скенерот GE Bright Speed 16 опремен со систем за AКЕ. Кај сите пациенти беше применет еден ист протокол со исти параметри на снимање и сликите беа реконструирани во стандарден мод. Димензиите на пациентите и шумот на сликите беа мерени на проекционите радиографии и на аксијалните пресеци. Од записот DICOM беа земени податоци поврзани со дозата, локацијата на пресекот и соодветната вредност на јачината на струјата. Беше утврдено дека системот за АКЕ ги нагодува параметрите на експозицијата главно во однос на најголемата латерална димензија на пациентот и дека примената на иста вредност на индексот на шумот не обезбедува секогаш ист шум на сликите кај пациенти со различна големина. Кај пациентите чијашто латерална димензија беше помала од $30 \mathrm{~cm}$, беше најдено дека АКЕ ја нагодува струјата на минималната вредност од избраниот интервал и дека таа не се менува за различни делови од телото.
\end{abstract}

Клучни зборови: одговор на системот за AКЕ; модулација на јачина на струјата во цевката; шум на сликата; индекс на шумот 
